\title{
Kesemiprimaan Aljabar Lintasan dan Aljabar Lintasan Leavit
}

\author{
Khurul Wardati \\ Program Studi Pendidikan Matematika Fakultas Sains dan Teknologi, UIN Sunan Kalijaga, Jl. Marsda \\ Adisucipto No. 1 Yogyakarta, Indonesia
}

Korespondensi; Email: ag_khurul@yahoo.co.id

\begin{abstract}
Abstrak
Aljabar lintasan $R E$ dan aljabar lintasan Leavitt $L_{R}(E)$ atas ring komutatif unital $R$ dikonstruksi dari semigrupring yang merupakan aljabar asosiatif dan bebas. Syarat perlu dan cukup $R E$ prima mendasar, semiprima mendasar dan $L_{R}(E)$ prima mendasar masing-masing berkaitan dengan struktur grafnya. Akan tetapi, kesemiprimaan $L_{R}(E)$ bergantung pada $R$ yang semiprima. Hal ini berakibat sebarang aljabar lintasan leavitt atas lapangan selalu semiprima.
\end{abstract}

Kata Kunci: semigrupring; prima mendasar; semiprima mendasar

\begin{abstract}
The path algebras $R E$ and The Leavitt path algebras $L_{R}(E)$ over a commutative unital ring $R$ are constructed by semigrouprings, and both are free associative algebras. Necessary and sufficient conditions of basically prime $R E$ and $L_{R}(E)$ and basically semiprime $R E$ are related to the structure of graph $E$. However, the semiprimeness of $L_{R}(E)$ are based on the semiprimeness of $R$. It implies that any Leavitt path algebra over field is always semiprime.
\end{abstract}

Keywords: semigroupring; basically prime; basically semiprime

\section{Pendahuluan}

Aljabar lintasan (path algebra) merupakan gabungan antara graf dan aljabar. Telaah tentang aljabar lintasan atas lapangan $K$ pada graf $E$ yang dinotasikan dengan $K E$ dapat dilihat [6] dan [7]. Beberapa sifat penting aljabar lintasan $K E$ yang telah dibahas dalam [7], antara lain: aljabar lintasan $K E$ merupakan aljabar bertingkat (graded algebra) yang asosiatif, $K E$ adalah aljabar unital jika graf $E$ berhingga, serta $K E$ berdimensi berhingga jika graf $E$ berhingga dan asiklis. Selain itu, hasil penelitian [6] adalah ditemukannya syarat perlu dan cukup pada suatu graf $E$ sedemikian sehingga aljabar lintasan $K E$ bersifat semiprima.

Sebarang graf $E$ dapat diperluas menjadi graf perluasan dengan notasi $\hat{E}$. Aljabar lintasan Leavitt (Leavitt path algebra) atas lapangan $K$ pada graf $E$ adalah aljabar lintasan $K \hat{E}$ yang memenuhi dua (2) syarat Cuntz-Krieger, yang selanjutnya dinotasikan dengan $L_{K}(E)$. Penelitian tentang aljabar lintasan Leavitt $L_{K}(E)$ terus berkembang yang menghasilkan teori-teori baru. Beberapa topik penelitian telah dilakukan dan diperoleh hasil antara lain: ditemukannya syarat perlu dan cukup pada graf $E$ sedemikian sehingga aljabar lintasan Leavitt $L_{K}(E)$ berdimensi hingga [4], $L_{K}(E)$ bersifat sederhana [1], $L_{K}(E)$ adalah Locally Finite atau Noether [2], dan $L_{K}(E)$ bersifat prima [5]. Hasil lain dari [6] bahwa $L_{K}(E)$ bersifat non-degenerate atau merupakan aljabar semiprima.

Sifat sederhana aljabar lintasan Leavitt $L_{K}(E)$ bergantung pada struktur graf yang memenuhi syarat tertentu dan bukan karena kesederhanaan lapangan $K$. Demikian pula syarat perlu dan cukup dari sifat-sifat $L_{K}(E)$ di atas juga bergantung pada struktur grafnya. Selain itu, kesemiprimaan aljabar 
lintasan $K E$ ditentukan pula oleh struktur grafnya. Hai inilah yang memotivasi pengembangan aljabar lintasan dan aljabar lintasan Leavitt pada ruang lingkup yang lebih umum.

Aljabar lintasan Leavitt atas ring komutatif $R$ dengan elemen satuan, yang dinotasikan dengan $L_{R}(E)$ telah dikaji oleh [9]. Sebagian sifat aljabar lintasan Leavitt $L_{K}(E)$ tetap bertahan dalam $L_{R}(E)$, namun ada beberapa sifat yang sedikit berbeda antara keduanya, seperti Teorema Ketunggalan Bertingkat dan Teorema Ketunggalan Cuntz-Krieger [10].

Temuan lain dari [9] adalah didefinisikannya ideal dasar (basic ideal) dari $L_{R}(E)$, di mana setiap ideal dari $L_{K}(E)$ adalah ideal dasar. Berdasarkan ideal dasar ini, didefinisikan sifat sederhana mendasar (basically simple) aljabar lintasan Leavitt $L_{R}(E)$, yaitu aljabar yang ideal dasarnya hanyalah ideal nol dan $L_{R}(E)$ sendiri [9]. Syarat perlu dan cukup aljabar lintasan Leavitt $L_{R}(E)$ sederhana mendasar sama dengan syarat perlu dan cukup $L_{K}(E)$ bersifat sederhana yang tergantung pada struktur grafnya. Artikel ini akan memberikan gagasan konseptual pengembangan aljabar lintasan dan aljabar lintasan Leavitt. Artikel dimulai dari bagaimana menggabungkan graf dengan aljabar sebagai konstruksi aljabar lintasan dan aljabar lintasan Leavitt. Pembahasan berikutnya adalah beberapa hasil penelitian berkaitan dengan sifat-sifat aljabar lintasan dan aljabar lintasan Leavitt atas ring komutatif unital. Sebelum bab penutup, akan dikaji pengembangan dan beberapa masalah terbuka (open problems) berkaitan dengan aljabar lintasan dan aljabar lintasan Leavitt.

\section{Konstruksi Aljabar Lintasan dan Aljabar Lintasan Leavitt}

Aljabar lintasan dan aljabar lintasan Leavitt dikonstruksi dari graf yang dipandang secara aljabar. Graf dalam artikel ini adalah graf berarah (directed graph) atau quiver yang tidak dipandang sebagai objek kombinatorik, dan selanjutnya hanya dikatakan dengan graf.

\section{Graf, Graf Perluasan dan Sifat-sifatnya}

Secara umum, graf dipandang sebagai sepasang himpunan $E=\left(\mathrm{E}^{0}, \mathrm{E}^{1}\right)$ dengan $E^{0}$ adalah himpunan tak kosong dari titik-titik (vertices) dan $E^{1}$ merupakan himpunan sisi-sisi (edges). Definisi graf secara aljabar yang digunakan dalam tulisan ini adalah sebagai berikut.

Definisi 1.1 [7] Graf $E=\left(E^{0}, E^{1}, s, r\right)$ terdiri dari himpunan titik-titik $E^{0}$ dan himpunan sisi-sisi $E^{1}$ yang menghubungkan titik di $E^{0}$ dengan fungsi-fungsi $s, r: E^{1} \rightarrow E^{0}$, secara berurutan didefinisikan $s(e)=$ sumber (source) dan $r(e)=$ ujung atau bayangan (range).

Graf dapat dipisahkan dengan tetap memperhatikan sisi dan titik di dalamnya. Sebagaimana himpunan, bagian dari graf yang dipisahkan dari graf aslinya disebut sebagai subgraf.

Definisi 1.2 [7] Diberikan graf $E=\left(E^{0}, E^{1}, s, r\right)$. Graf $E^{\prime}=\left(\left(E^{\prime}\right)^{0},\left(E^{\prime}\right)^{1}, s^{\prime}, r^{\prime}\right)$ adalah subgraf dari $E_{,}$jika $\left(E^{\prime}\right)^{0} \subseteq E^{0},\left(E^{\prime}\right)^{1} \subseteq E^{1}, s^{\prime}=\left.s\right|_{\left(E^{\prime}\right)^{1}}$ dan $r^{\prime}=\left.r\right|_{\left(E^{\prime}\right)^{1}}$. Jika $\left(E^{\prime}\right)^{1}=\left\{e \in E^{1}: s(e), r(e) \in\left(E^{\prime}\right)^{1}\right\}$ maka $E^{\prime}$ disebut subgraf penuh dari $E$.

Lintasan $\mu$ dalam graf $E$ yang panjangnya $k$ adalah barisan sisi-sisi, katakan $\mu=e_{1} e_{2} \ldots e_{k}$ dengan $e_{i} \in E^{1}$ dan $r\left(e_{i}\right)=s\left(e_{i+1}\right)$ untuk $i=1,2, \ldots, k-1$. Sumber dan ujung dari lintasan $\mu$ secara berurutan dinotasikan oleh $s(\mu)$ dan $r(\mu)$ dengan $s(\mu)=s\left(e_{1}\right)$ dan $r(\mu)=r\left(e_{k}\right)$. Setiap titik $v \in$ $E^{0}$ diasosiasikan dengan lintasan yang panjangnya 0 dan disebut lintasan trivial atau stasioner, sedangkan setiap sisi e $\in E^{1}$ merupakan lintasan yang panjangnya 1 . Suatu sisi $f \in E^{1}$ disebut sisi keluar (exit) dari lintasan $\mu=e_{1} e_{2} \ldots e_{k}$, jika terdapat $i$ sedemikian sehingga $s(f)=s\left(e_{i}\right)$ dan $f \neq e_{i}$. Lintasan $\mu=e_{1} e_{2} \ldots e_{k}$ disebut sikel (Cycle) jika sumber dan ujungnya sama dan tidak ada sisi yang diulang, dengan kata lain, $r(\mu)=s(\mu)$ dan untuk setiap $i \neq j, s\left(e_{i}\right) \neq s\left(e_{j}\right)$. Sikel yang panjangnya 1 disebut loop. Himpunan semua lintasan dalam graf $E$ dinotasikan dengan Path(E).

Operasi perkalian sebarang dua lintasan dapat didefinisikan pada Path(E). Definisi operasi perkalian ini digunakan untuk mendefinisikan aljabar lintasan. 
Definisi 1.3 [7] Diberikan graf $E=\left(E^{0}, E^{1}, s, r\right)$ dan lintasan $\mu, \vartheta \in \operatorname{Path}(E)$. dengan $\mu=$ $e_{1} e_{2} \ldots e_{m} ; \vartheta=f_{1} f_{2} \ldots f_{n}$ yang secara berturutan bersumber di $a, c$ dan berujung di $b, d$ untuk suatu $a, b, c, d \in E^{0}$. Operasi dua lintasan $\mu$ dan $\vartheta$ adalah

$$
\mu \vartheta=\left\{\begin{array}{cc}
e_{1} e_{2} \ldots e_{m} f_{1} f_{2} \ldots f_{n}, & , j \text { jika } r\left(e_{m}\right)=s(f) \\
0 & , j \text { jika } r\left(e_{m}\right) \neq s(f)
\end{array}\right.
$$

dengan 0 dikatakan sebagai lintasan nol.

Graf $E$ dapat diperluas dengan memandang arah sebaliknya dari sisi-sisi dalam $E^{1}$. Sisi dalam $E^{1}$ disebut sisi real (real edge) dan sisi dengan arah sebaliknya disebut sisi hantu (ghost edge). Himpunan semua sisi hantu dalam graf $E$ dinyatakan dengan $\left(E^{1}\right)^{*}$. Berikut diberikan definisi dari graf yang diperluas.

Definisi 1.4 [4] Graf perluasan (extended graph) dari graf $E=\left(E^{0}, E^{1}, s, r\right)$ adalah graf baru $\hat{E}=$ $\left(E^{0}, E^{1} \cup\left(E^{1}\right)^{*}, s^{\prime}, r^{\prime}\right)$ dengan $\left(E^{1}\right)^{*}=\left\{e^{*} \mid e \in E^{1}\right\}$ himpunan semua sisi hantu dan fungsi $s^{\prime}, r^{\prime}$ adalah $\left.s^{\prime}\right|_{E^{1}}=s,\left.r^{\prime}\right|_{E^{1}}=r, s^{\prime}\left(e^{*}\right)=r(e), r^{\prime}\left(e^{*}\right)=s(e)$.

Beberapa sifat aljabar ditentukan oleh sifat ideal-idealnya. Ideal dalam aljabar lintasan dan aljabar lintasan Leavitt dapat dibentuk oleh subhimpunan dari $E^{0}$ dengan sifat khusus yang disebut herediter (hereditary). Sifat herediter berkaitan dengan relasi mendahului (preorder) " $\leq "$ : untuk setiap $v, w \in$ $E^{0}, v \leq w$ jika dan hanya jika $v=w$ atau terdapat lintasan $\mu$ sehingga $s(\mu)=v, r(\mu)=w$. Selain herediter, sifat lain dari subhimpunan dari $E^{0}$ adalah tersaturasi (saturated).

Definisi 1.5 [1] Subhimpunan $H \subseteq E^{0}$ disebut herediter jika untuk setiap $v, w \in E^{0}$ dengan $v \leq w, v \in$ $H$ berakibat $w \in H$. Subhimpunan $H$ dikatakan tersaturasi jika untuk setiap $v \in E^{0}$ dengan $s^{-1}(v) \neq$ $\emptyset, \mathrm{r}\left(s^{-1}(v)\right) \subseteq \mathrm{H}$ berakibat $v \in H$. Penyaturasi subhimpunan herediter $H$ dinotasikan dengan $\bar{H}$.

Dua buah subhimpunan herediter, gabungan dan irisan keduanya merupakan subhimpunan herediter. Namun, gabungan dua buah subhimpunan tersaturasi belum tentu tersaturasi, meskipun irisan dua subhimpunan tersaturasi selalu tersaturasi. Komplemen dari subhimpunan herediter tersaturasi yang memenuhi kondisi ekor maksimal (maximal tail) berpengaruh pada keprimaan ideal dalam aljabar lintasan dan aljabar lintasan Leavitt.

Definisi 1.6 [5] Subhimpunan tak kosong $M \subseteq E^{0}$ disebut memenuhi kondisi ekor maksimal jika $M$ memenuhi sifat-sifat :

(MT1) Jika $v \in E^{0}, w \in M$ dan $v \leq w$ maka $v \in M$

(MT2) Jika $v \in M$ dengan $s^{-1}(v) \neq \varnothing$ maka terdapat $e \in E^{1}$ dengan $s(e)=v$ dan $r(e) \in M$.

(MT3) Untuk setiap $v, w \in M$ terdapat $y \in M$ sehingga $v \leq y, w \leq y$.

Contoh 1.7 Perhatikan Gambar 1, $M=\left\{v_{0}, v_{1}, v_{2}\right\}$ merupakan ekor maksimal, sedangkan $E^{0}$ bukan ekor maksimal karena $E^{0}$ tidak memenuhi (MT3) : $\exists v_{2}, v_{3} \in E^{0}$ dengan $v_{2} \$ v, v_{3} \$ v, \forall v \in E^{0}$. Subhimpunan $L=\left\{v_{1}, v_{2}, v_{3}\right\}$ dan $N=\left\{v_{0}, v_{1}\right\}$ keduanya bukan ekor maksimal karena $L$ tidak memenuhi (MT1) dan $N$ tidak memenuhi (MT2). Hal ini dikarenakan $v_{1} \in L, v_{0} \leq v_{1}$ tetapi $v_{0} \notin L$, dan karena $s^{-1}\left(v_{1}\right) \neq \varnothing$ tetapi $\forall e \in E^{1}$ dengan $r(e)=v_{1}, r(e) \notin N$.

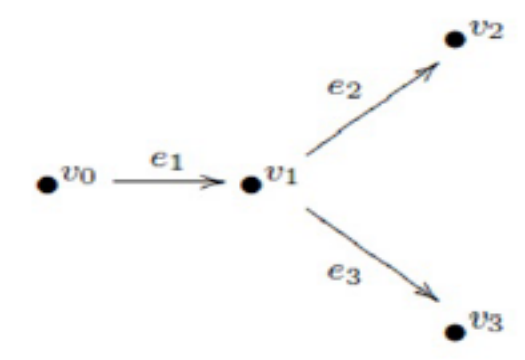

Gambar 1 Ilustrasi Kondisi Ekor Maksimal. 
Perhatikan kembali Gambar 1 dan Contoh 1.6, $E^{0} \backslash M=\left\{v_{3}\right\}$ bersifat herediter dan tersaturasi, $E^{0} \backslash L=\left\{v_{0}\right\}$ tidak herediter namun tersaturasi, dan $E^{0} \backslash N=\left\{v_{2}, v_{3}\right\}$ herediter tetapi tidak tersaturasi. $\mathrm{Hal}$ ini mengilustrasikan keterkaitan antara kondisi ekor maksimal dengan sifat herediter tersaturasi.

Lemma 1.8 [5] Diberikan graf $E$ dan $H \subset E^{0}$. Subhimpunan $H$ bersifat herediter dan tersaturasi jika dan hanya jika $M=E^{0} \backslash H$ memenuhi kondisi (MT1) dan (MT2).

Menurut [6], aljabar lintasan $K E$ atas lapangan $K$ pada graf $E$ merupakan subaljabar bertingkat dari aljabar lintasan Leavitt $L_{K}(E)$. Perlunya dikaji aljabar lintasan atas ring komutatif unital $R$ beserta sifat-sifatnya, termotivasi dari [9] yaitu perumuman aljabar lintasan Leavitt $L_{R}(E)$ dari $L_{K}(E)$.

\section{Aljabar Lintasan Atas Ring Komutatif Unital dan Sifat-sifatnya}

Jika diperhatikan Definisi 1.2, operasi perkalian dua buah lintasan dalam persamaan (1) dan diasumsikan adanya lintasan nol dalam graf $E$, maka himpunan semua lintasan Path(E) dapat dipandang sebagai semigrup. Menurut [8], semigrup ring dari Path(E) atas ring komutatif unital $R$ yang dinotasikan dengan $R($ Path $(E))$ adalah himpunan kombinasi linear berhingga Path(E) atas $R$ dan merupakan $R$-aljabar asosiatif dengan basis Path(E). Aljabar bebas $R($ Path(E)) yang memenuhi syarat tertentu disebut aljabar lintasan atas $R$, yang selanjutnya dinotasikan dengan $R E$.

Definisi 2.1 [12] Diberikan ring komutatif unital $R$ dan graf $E$. Aljabar lintasan pada graf $E$ atas $R$ adalah $R$-aljabar bebas $R E$ dengan basis himpunan semua lintasan Path(E) yang memenuhi :

1. $v_{i} v_{j}=\delta_{i j} v_{i}$ untuk setiap $v_{i}, v_{j} \in E^{0}$

2. $e_{i}=e_{i} r\left(e_{i}\right)=s\left(e_{i}\right) e_{i}$ untuk setiap $e_{i} \in E^{1}$.

Berdasarkan Definisi 2.1 poin 1, sebarang titik dari suatu graf merupakan elemen idempoten dalam aljabar $R E$. Selain itu, sebarang dua titik berlainan akan membentuk pasangan elemen idempoten ortogonal di RE. Perhatikan contoh graf dan representasi aljabarnya berikut.

Contoh 2.2 Gambar 2 melukiskan graf $D, F, G$ dengan $D^{0}=\{v\}, D^{1}=\{e\}, F^{0}=\left\{u_{1}, u_{2}, u_{3}, u_{4}\right\}, F^{1}=$ $\left\{e_{1}, e_{2}, e_{3}\right\}$ dan $G^{0}=\{u, w\}, G^{1}=\{f, g\}$.

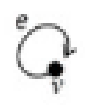

Guf $D$

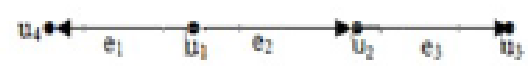

Graf $F$

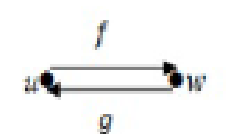

Graf G

Gambar 2 Ilustrasi Aljabar Lintasan.

1. Graf $D$ memuat loop e maka $\operatorname{Path}(D)=\left\{v, e, e^{2}, \cdots, e^{n}, \cdots\right\}$ basis tak berhingga dari aljabar lintasan $R D \cong R[t]$, jika $v \mapsto 1, e \mapsto t$ (peubah indeterminate).

2. Aljabar lintasan $R F$ adalah $R$-aljabar bebas dengan basis berhingga Path $(F)=$ $\left\{u_{1}, u_{2}, u_{3}, u_{4}, e_{1}, e_{2}, e_{3}, e_{2} e_{3}\right\}$. Lintasan-lintasan ini dapat direpresentasikan oleh bentuk matriks unit berikut:

$$
\begin{aligned}
& u_{1} \mapsto\left(\begin{array}{cccc}
1 & 0 & 0 & 0 \\
0 & 0 & 0 & 0 \\
0 & 0 & 0 & 0 \\
0 & 0 & 0 & 0
\end{array}\right), u_{2} \mapsto\left(\begin{array}{cccc}
0 & 0 & 0 & 0 \\
0 & 1 & 0 & 0 \\
0 & 0 & 0 & 0 \\
0 & 0 & 0 & 0
\end{array}\right), u_{3} \mapsto\left(\begin{array}{cccc}
0 & 0 & 0 & 0 \\
0 & 0 & 0 & 0 \\
0 & 0 & 1 & 0 \\
0 & 0 & 0 & 0
\end{array}\right) \text {, } \\
& u_{4} \mapsto\left(\begin{array}{cccc}
0 & 0 & 0 & 0 \\
0 & 0 & 0 & 0 \\
0 & 0 & 0 & 0 \\
0 & 0 & 0 & 1
\end{array}\right), e_{1} \mapsto\left(\begin{array}{cccc}
0 & 0 & 0 & 1 \\
0 & 0 & 0 & 0 \\
0 & 0 & 0 & 0 \\
0 & 0 & 0 & 0
\end{array}\right), e_{2} \mapsto\left(\begin{array}{llll}
0 & 1 & 0 & 0 \\
0 & 0 & 0 & 0 \\
0 & 0 & 0 & 0 \\
0 & 0 & 0 & 0
\end{array}\right)
\end{aligned}
$$




$$
e_{3} \mapsto\left(\begin{array}{cccc}
0 & 0 & 0 & 0 \\
0 & 0 & 1 & 0 \\
0 & 0 & 0 & 0 \\
0 & 0 & 0 & 0
\end{array}\right), e_{2} e_{3} \mapsto\left(\begin{array}{cccc}
0 & 0 & 1 & 0 \\
0 & 0 & 0 & 0 \\
0 & 0 & 0 & 0 \\
0 & 0 & 0 & 0
\end{array}\right) \text {, sehingga } R F \cong\left(\begin{array}{cccc}
R & R & R & R \\
0 & R & R & 0 \\
0 & 0 & R & 0 \\
0 & 0 & 0 & R
\end{array}\right)
$$

3. Graf $G$ memuat dua buah sikel $f g, g f$ dengan $s(f g)=r(g f), s(g f)=r(f g)$. Aljabar lintasan $R G$ mempunyai basis tak berhingga,

$\operatorname{Path}(G)=\left\{u, w, f, g, f g, g f, f g f, g f g, \cdots,(f g)^{n},(g f)^{n},(f g)^{n} f,(g f)^{n} g, \cdots\right\} . \quad$ jika diperhatikan berlakunya Definisi 2.2.1, maka elemen-elemen basis tersebut dapat direpresentasikan sebagai :

$$
\begin{aligned}
& u \mapsto\left(\begin{array}{ll}
1 & 0 \\
0 & 0
\end{array}\right), w \mapsto\left(\begin{array}{ll}
0 & 0 \\
0 & 1
\end{array}\right), f \mapsto\left(\begin{array}{ll}
0 & t \\
0 & 0
\end{array}\right), g \mapsto\left(\begin{array}{ll}
0 & 0 \\
t & 0
\end{array}\right), f g \mapsto\left(\begin{array}{cc}
t^{2} & 0 \\
0 & 0
\end{array}\right), \\
& g f \mapsto\left(\begin{array}{cc}
0 & 0 \\
0 & t^{2}
\end{array}\right), f g f \mapsto\left(\begin{array}{cc}
0 & t^{3} \\
0 & 0
\end{array}\right), g f g \mapsto\left(\begin{array}{cc}
0 & 0 \\
t^{3} & 0
\end{array}\right), \cdots,(f g)^{n} \mapsto\left(\begin{array}{cc}
t^{2 n} & 0 \\
0 & 0
\end{array}\right), \\
& (g f)^{n} \mapsto\left(\begin{array}{cc}
0 & 0 \\
0 & t^{2 n}
\end{array}\right),(f g)^{n} f=f(g f)^{n} \mapsto\left(\begin{array}{cc}
0 & t^{2 n+1} \\
0 & 0
\end{array}\right), \\
& g(f g)^{n}=(g f)^{n} g \mapsto\left(\begin{array}{cc}
0 & 0 \\
t^{2 n+1} & 0
\end{array}\right) \text {. Aljabar lintasan } R G \cong\left(\begin{array}{cc}
R\left[t^{2}\right] & R\left[t^{2}\right] t \\
R\left[t^{2}\right] t & R\left[t^{2}\right]
\end{array}\right) .
\end{aligned}
$$

Perhatikan Contoh 2.2, jika dicermati representasi masing-masing maka jumlah dari semua titiknya dapat direpresentasikan dengan elemen satuan dalam matriks. Selain berhingga, graf $F$ adalah asiklis dan aljabar lintasan $R F$ memiliki basis berhingga. Namun, graf $D$ dan $G$ tidak asiklis dan aljabar lintasannya memiliki basis tak berhingga. Uraian ini menginspirasikan bahwa selain merupakan aljabar asosiatif, aljabar lintasan mempunyai sifat lain yang dinyatakan dalam proposisi berikut.

Proposisi 2.3 [12] Jika diberikan aljabar lintasan $R E$, maka :

1. RE adalah aljabar asosiatif bertingkat (graded associative algebra)

2. $R E$ adalah aljabar unital jika dan hanya jika $E^{0}$ berhingga

3. $R E$ berdimensi berhingga jika dan hanya jika $E$ berhingga dan asiklis.

Aljabar lintasan merupakan $R$-aljabar bebas yang beberapa sifatnya berkaitan dengan sifat idealnya. Definisi ideal dasar (basic ideal) dalam aljabar lintasan Leavitt atas ring komutatif unital $L_{R}(E)$ dapat diperumum menjadi ideal dasar dalam $R$-aljabar bebas. Perumuman tersebut akan digunakan untuk mengkonstruksi ideal dasar dalam aljabar lintasan $R E$.

Definisi 2.4 [13] Diberikan $R$-aljabar bebas $A$. Ideal $I \subseteq A$ disebut ideal dasar dalam $A$, jika untuk setiap elemen tak nol $r \in R, x \in X$ sedemikian hingga $r x \in I$, berakibat $x \in I$, untuk sebarang basis $X \subset A$.

Jika ring komutatif unital $R$ digantikan dengan lapangan $K$ maka ideal dari $K$-aljabar bebas $A$ merupakan ideal dasar. Hal ini dikarenakan setiap elemen dalam lapangan $K$ mempunyai invers. Tampak jelas dari Definisi 2.4 bahwa ideal nol dan $A$ selalu merupakan ideal dasar.

Berdasarkan definisi ideal sisi dalam $K E$ [7], dapat didefinisikan ideal sisi $I_{E}$ dalam $R E$ yaitu $I_{E}=$ $\operatorname{Span}_{R}\left\{\mu \in \operatorname{Path}(E) \backslash E^{0}\right\}$ yang elemen-elemennya merupakan kombinasi linear dari lintasan-lintasan dengan panjang $l \geq 1$ [12[. Jadi, $I_{E}$ merupakan ideal dasar yang tak memuat titik. Ideal $I_{E}$ diperumum menjadi ideal dasar yang memuat titik dan dikonstuksi dari subset herediter.

Definisi 2.5 [12] Diberikan graf $E$ dan subhimpunan herediter $H \subseteq E^{0}$. Ideal dasar dalam $R E$ yang memuat $H$ adalah :

$$
I_{H}=\operatorname{Span}_{R}\{\mu \in \operatorname{Path}(E): r(\mu) \in H \vee \mu \in H\}
$$

Berdasarkan definisi ideal dasar dalam $L_{R}(E)$, telah didefinisikan sifat sederhana mendasar (basically simple) [9]. Sifat lain yang juga berkaitan dengan sifat ideal dasarnya, adalah sifat prima mendasar (basically prime) yang bergantung pada keprimaan ideal dasar nol. 
Definisi 2.6 [12] Diberikan $R$-aljabar bebas $A$ dan ideal dasar $I \subseteq A$. Ideal / disebut ideal dasar prima jika $I \neq A$ dan untuk setiap $P, Q$ ideal dasar di $A$, jika $P Q \subseteq I$ maka $P \subseteq I$ atau $Q \subseteq I$. Ideal I dikatakan ideal dasar semiprima, jika $I \neq A$ dan untuk setiap ideal dasar $P$ di $A$, jika $P^{2} \subseteq I$ maka $P \subseteq I$. Aljabar $A$ bersifat (semi) prima mendasar jika ideal dasar nolnya merupakan ideal dasar (semi) prima.

Keprimaan ideal dasar $I_{H}$ dalam persamaan (2) bergantung pada struktur grafnya, demikian pula ideal dasar $\{0\}=I_{\emptyset}$. Berikut diberikan syarat perlu dan cukup suatu ideal dasar dalam aljabar lintasan $R E$ merupakan ideal dasar prima, yang berakibat ditemukannya syarat perlu dan cukup aljabar lintasan $R E$ bersifat prima mendasar.

Teorema 2.7 [12] Diberikan aljabar lintasan $R E$ dan subhimpunan herediter tersaturasi $H \subset E^{0}$. Ideal $I_{H}$ dalam persamaan (2) adalah ideal dasar prima jika dan hanya jika $M=E^{0} \backslash H$ adalah ekor maksimal dan untuk setiap lintasan $\mu$ dengan $r(\mu) \in M$, terdapat lintasan $\vartheta \in \operatorname{Path}(E)$ sehingga $r(\mu)=s(\vartheta)$ dan $s(\mu)=r(\vartheta)$.

Bukti Teorema 2.7 cukup panjang, dapat dilihat dalam bukti [12, Theorem 4.6]. Ideal dasar $I_{H}$ yang memuat $\mathrm{H}$ menurut Definisi 2.5 adalah herediter dan tidak harus tersaturasi. Namun dengan Lemma 1.8, subhimpunan herediter $H$ dalam Teorema 2.7 mengharuskan tersaturasi, agar $M=E^{0} \backslash H$ memenuhi kondisi (MT1) dan (MT2). Artinya, jika $H$ tidak tersaturasi, pastilah ideal dasar $I_{H}$ tidak prima.

Subhimpunan $\emptyset$ bersifat herediter dan tersaturasi, sehingga $E^{0}$ memenuhi kondisi (MT1) dan (MT2) menurut Lemma 1.8. Karena ideal dasar $\{0\}=I_{\varnothing}$ dan berdasarkan Definisi 2.6, maka Teorema 2.7 memiliki akibat berikut.

Akibat 2.8 [12] Aljabar lintasan $R E$ merupakan aljabar prima mendasar jika dan hanya jika $E^{0}$ memenuhi kondisi $(M T 3)$ dan untuk setiap lintasan $\mu$, terdapat lintasan $\vartheta$ sedemikian sehingga $r(\mu)=$ $s(\vartheta)$ dan $s(\mu)=r(\vartheta)$.

Akibat 2.8 memperlihatkan syarat perlu dan cukup keprimaan mendasar aljabar lintasan $R E$ atas ring komutatif unital $R$. Karena sebarang ideal dalam KE merupakan ideal dasar, maka syarat perlu dan cukup keprimaan aljabar lintasan $K E$ atas lapangan sama persis dalam akibat 2.8 tersebut.

Contoh 2.9 Perhatikan kembali Gambar 2 pada Contoh 2.2 di atas, bahwa ideal $\{0\}$ dalam aljabar lintasan $R D$ dan $R G$ merupakan ideal dasar prima, sehingga $R D$ dan $R G$ merupakan aljabar litasan yang prima mendasar. Karena $F^{0}$ tidak memenuhi kondisi (MT3), yakni $\exists u_{2}, u_{4} \in F^{0}$ dengan $u_{2} \not$ $u \vee u_{4} \Varangle u, \forall u \in F^{0}$ maka ideal nol dalam $R F$ tidak prima, sehingga $R F$ aljabar lintasan yang tidak prima mendasar.

Berdasarkan perluasan graf pada Definisi 1.4, dapat dikonstruksi aljabar lintasan $R \hat{E}$ pada graf perluasan, secara sama dengan konstruksi aljabar lintasan $R E$. Aljabar lintasan $R \hat{E}$ yang memenuhi syarat Cuntz-Krieger disebut aljabar lintasan Leavitt, yang konstruksi dan beberapa sifatnya akan dibahas pada subbab berikut.

\section{Aljabar Lintasan Leavitt Atas Ring Komutatif Unital dan Sifatnya}

Aljabar lintasan Leavitt adalah aljabar lintasan pada graf perluasan (Definisi 1.3) $\hat{E}=$ $\left(E^{0}, E^{1} \cup\left(E^{1}\right)^{*}, s^{\prime}, r^{\prime}\right)$ yang memenuhi syarat tertentu. Agak berbeda dengan konstruksi aljabar lintasan Leavitt atas lapangan, [9] mengkonstruksi aljabar lintasan Leavitt dengan keluarga Leavitt atas ring pada suatu graf. Berikut diberikan definisi aljabar lintasan Leavitt atas ring komutatif unital $R$, yang mengkombinasikan definisi $L_{K}(E)$ oleh [4] dan $L_{R}(E)$ oleh [9].

Definisi 3.1 [11] Diberikan graf $E$ maka aljabar lintasan Leavitt atas ring komutatif unital $R$ yang dinotasikan $L_{R}(E)$ adalah R-aljabar bebas yang memenuhi :

1. $v_{i} v_{j}=\delta_{i j} v_{i}$ untuk setiap $v_{i}, v_{j} \in E^{0}$,

2. $\operatorname{er}(e)=s(e) e=e \operatorname{dan} e^{*} s(e)=r(e) e^{*}=e^{*}$ untuk setiap $e \in E^{1}$, 
3. $e^{*} f=\delta_{e, f} r(e)$ untuk setiap $e \in E^{1}$, dan

4. $v=\sum_{e \in E^{1}: s(e)=v} e e^{*}$ untuk setiap titik $v \in E^{0}, s^{-1}(v) \neq \emptyset$.

Perhatikan bahwa syarat 1. dan 2. dalam Definisi 3.1, merupakan syarat aljabar lintasan (Definisi 2.1) pada graf perluasan $\hat{E}$ dan syarat ke 3. dan 4. disebut syarat Cuntz-Krieger yang secara berurutan disingkat dengan $C K 1, C K 2$. Jadi, aljabar lintasan Leavitt $L_{R}(E)$ merupakan $R$-aljabar asosiatif yang terbentuk dari semigrup ring $R \hat{E}$, yakni terdiri semua lintasan dalam graf perluasan $\hat{E}$ dan memenuhi syarat Cuntz-Krieger.

Perhatikan graf $F$ pada Gambar 2 yang telah dilengkapi dengan sisi hantu (Definisi 1.3), dilukiskan sebagai berikut:

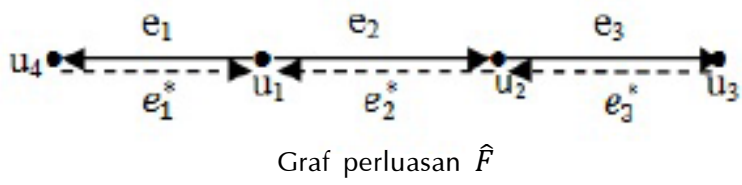

Gambar 3 Ilustrasi Aljabar Lintasan Leavitt.

Aljabar lintasan $R \hat{F} \cong\left(\begin{array}{llll}R & R & R & R \\ R & R & R & 0 \\ R & R & R & 0 \\ R & 0 & 0 & R\end{array}\right)$ pada Contoh 2.2 di atas tidak memenuhi syarat $C K 2$ karena $s^{-1}\left(u_{1}\right)=\left\{e_{1}, e_{1}\right\}$ dan $u_{1} \neq e_{1} e_{1}^{*}+e_{2} e_{2}^{*}$ dengan $e_{1}^{*} \mapsto\left(\begin{array}{cccc}0 & 0 & 0 & 0 \\ 0 & 0 & 0 & 0 \\ 0 & 0 & 0 & 0 \\ 1 & 0 & 0 & 0\end{array}\right), e_{2}^{*} \mapsto\left(\begin{array}{cccc}0 & 0 & 0 & 0 \\ 1 & 0 & 0 & 0 \\ 0 & 0 & 0 & 0 \\ 0 & 0 & 0 & 0\end{array}\right)$.

Berdasarkan [7], representasi aljabar lintasan tidak tunggal. Berikut diberikan contoh aljabar lintasan dari graf perluasan $\hat{F}$ yang memenuhi $C K 1$, dan $C K 2$.

Contoh 3.2 Diberikan graf perluasan $\hat{F}$ (Gambar 2.3) dengan $\left(F^{1}\right)^{*}=\left\{e_{1}^{*}, e_{2}^{*}, e_{3}^{*}\right\}$ dan ring komutatif unital $R$. Berdasarkan syarat $C K 2$, karena $S^{-1}\left(u_{1}\right)=\left\{e_{1}, e_{1}\right\}$ maka haruslah berlaku $u_{1}=e_{1} e_{1}^{*}+$ $e_{2} e_{2}^{*}$. Terdapat dua buah titik $u_{3}, u_{4} \in F^{0}$ dengan $s^{-1}\left(u_{3}\right)=s^{-1}\left(u_{4}\right)=\emptyset$ dan graf $F$ dapat dipisahkan menjadi dua subgraf tak penuh $F_{1}, F_{2}$ dengan $F_{1}^{0}=\left\{u_{1}, u_{2}, u_{3}\right\}, F_{1}^{1}=\left\{e_{2}, e_{3}\right\}, F_{2}^{0}=$ $\left\{u_{1}, u_{4}\right\}, F_{2}^{1}=\left\{e_{1}\right\}$. Jika diperhatikan syarat $C K 2$, maka lintasan dalam Path(F) dapat direpresantasikan sebagai pasangan berurutan matriks-matriks unit sebagai berikut:

$$
\begin{aligned}
& u_{1} \mapsto\left[\left(\begin{array}{lll}
1 & 0 & 0 \\
0 & 0 & 0 \\
0 & 0 & 0
\end{array}\right),\left(\begin{array}{ll}
1 & 0 \\
0 & 0
\end{array}\right)\right] ; u_{2} \mapsto\left[\left(\begin{array}{lll}
0 & 0 & 0 \\
0 & 1 & 0 \\
0 & 0 & 0
\end{array}\right),\left(\begin{array}{ll}
0 & 0 \\
0 & 0
\end{array}\right)\right] ; \\
& u_{3} \mapsto\left[\left(\begin{array}{lll}
0 & 0 & 0 \\
0 & 0 & 0 \\
0 & 0 & 1
\end{array}\right),\left(\begin{array}{ll}
0 & 0 \\
0 & 0
\end{array}\right)\right] ; u_{4} \mapsto\left[\left(\begin{array}{lll}
0 & 0 & 0 \\
0 & 0 & 0 \\
0 & 0 & 0
\end{array}\right),\left(\begin{array}{ll}
0 & 0 \\
0 & 1
\end{array}\right)\right] ; \\
& e_{1} \mapsto\left[\left(\begin{array}{lll}
0 & 0 & 0 \\
0 & 0 & 0 \\
0 & 0 & 0
\end{array}\right),\left(\begin{array}{ll}
0 & 1 \\
0 & 0
\end{array}\right)\right] ; e_{2} \mapsto\left[\left(\begin{array}{lll}
0 & 1 & 0 \\
0 & 0 & 0 \\
0 & 0 & 0
\end{array}\right),\left(\begin{array}{ll}
0 & 0 \\
0 & 0
\end{array}\right)\right] ; \\
& e_{3} \mapsto\left[\left(\begin{array}{lll}
0 & 0 & 0 \\
0 & 0 & 1 \\
0 & 0 & 0
\end{array}\right),\left(\begin{array}{ll}
0 & 0 \\
0 & 0
\end{array}\right)\right] ; e_{2} e_{3} \mapsto\left[\left(\begin{array}{lll}
0 & 0 & 1 \\
0 & 0 & 0 \\
0 & 0 & 0
\end{array}\right),\left(\begin{array}{ll}
0 & 0 \\
0 & 0
\end{array}\right)\right]
\end{aligned}
$$

Representasi tersebut memenuhi Definisi 2.1, sehingga $R F$ merupakan aljabar lintasan dengan setiap elemennya merupakan kombinasi linear dari ke delapan elemen dalam Path $(F)=$ $\left\{u_{1}, u_{2}, u_{3}, u_{4}, e_{1}, e_{2}, e_{3}, e_{2} e_{3}\right\}$ dan diperoleh bahwa: 


$$
R F \cong\left[\left(\begin{array}{ccc}
R & R & R \\
0 & R & R \\
0 & 0 & R
\end{array}\right),\left(\begin{array}{ll}
R & R \\
0 & R
\end{array}\right)\right]=T_{3}(R) \times T_{2}(R) .
$$

Sisi hantu dan lintasan-lintasan lain dalam graf perluasan $\hat{F}$ direpresentasikan sebagai:

$$
\begin{gathered}
e_{1}^{*} \mapsto\left[\left(\begin{array}{lll}
0 & 0 & 0 \\
0 & 0 & 0 \\
0 & 0 & 0
\end{array}\right),\left(\begin{array}{ll}
0 & 0 \\
1 & 0
\end{array}\right)\right] ; e_{2}^{*} \mapsto\left[\left(\begin{array}{lll}
0 & 0 & 0 \\
1 & 0 & 0 \\
0 & 0 & 0
\end{array}\right),\left(\begin{array}{ll}
0 & 0 \\
0 & 0
\end{array}\right)\right] ; \\
\left.e_{3}^{*} \mapsto\left[\left(\begin{array}{lll}
0 & 0 & 0 \\
0 & 0 & 0 \\
0 & 1 & 0
\end{array}\right),\left(\begin{array}{ll}
0 & 0 \\
0 & 0
\end{array}\right)\right] ;\left(e_{2} e_{3}\right)^{*}=e_{3}^{*} e_{2}^{*} \mapsto\left[\begin{array}{lll}
0 & 0 & 0 \\
0 & 0 & 0 \\
1 & 0 & 0
\end{array}\right),\left(\begin{array}{ll}
0 & 0 \\
0 & 0
\end{array}\right)\right] ; \\
e_{1} e_{1}^{*} \mapsto\left[\left(\begin{array}{lll}
0 & 0 & 0 \\
0 & 0 & 0 \\
0 & 0 & 0
\end{array}\right),\left(\begin{array}{ll}
1 & 0 \\
0 & 0
\end{array}\right)\right] ; e_{2} e_{2}^{*} \mapsto\left[\left(\begin{array}{ccc}
1 & 0 & 0 \\
0 & 0 & 0 \\
0 & 0 & 0
\end{array}\right),\left(\begin{array}{ll}
0 & 0 \\
0 & 0
\end{array}\right)\right] ;
\end{gathered}
$$

sehingga $u_{1}=e_{1} e_{1}^{*}+e_{2} e_{2}^{*}$.

Tampak bahwa aljabar lintasan $R \hat{F}$ memenuhi syarat Cuntz-Krieger, sehingga diperoleh aljabar lintasan Leavitt atas ring komutatif unital $R$,

$$
L_{R}(F) \cong\left[\left(\begin{array}{lll}
R & R & R \\
R & R & R \\
R & R & R
\end{array}\right),\left(\begin{array}{ll}
R & R \\
R & R
\end{array}\right)\right]=M_{3}(R) \times M_{2}(R) .
$$

Proposisi 3.4. dalam Tomforde (2011) telah dibuktikan bahwa himpunan $\left\{v, e, e^{*}: v \in E^{0}, e \in\right.$ $\left.E^{1}, e^{*} \in\left(E^{1}\right)^{*}\right\}$ terdiri dari elemen-elemen tidak nol dan $c v \neq 0$ untuk setiap elemen tak nol $c \in$ $R, v \in E^{0}$. Berdasarkan kondisi Cuntz-Krieger maka elemen-elemen pembangun $L_{R}(E)$ berbentuk monomial $\alpha \beta^{*}$ dengan $\alpha, \beta \in \operatorname{Path}(E), r(\alpha)=r(\beta)$, dan asumsi bahwa untuk setiap titik $u \in$ $E^{0}, u^{*}=u=r(u)=s(u)$. Misalkan himpunan semua elemen pembangun $L_{R}(E)$ ditulis Mon $(E)$, maka :

$$
\operatorname{Mon}(E)=\left\{\alpha \beta^{*}: \alpha, \beta \in \operatorname{Path}(E), r(\alpha)=r(\beta)\right\}
$$

Contoh 3.3 Perhatikan kembali graf perluasan $\hat{F}$ (Gambar 3) dan Contoh 3.2, maka Mon $(F)=$ $\left\{u_{1}, u_{2}, u_{3}, u_{4}, e_{1}, e_{2}, e_{3}, e_{2} e_{3}, e_{1}^{*}, e_{2}^{*}, e_{3}^{*}, e_{1} e_{1}^{*}, e_{2} e_{2}^{*}, e_{3}^{*} e_{2}^{*}\right\}$ merupakan pembangun $L_{R}(F)$. Karena $u_{1}=$ $e_{1} e_{1}^{*}+e_{2} e_{2}^{*}$ maka $\operatorname{Mon}(F)$ tidak bebas linear, yang berarti $\operatorname{Mon}(F)$ bukan basisnya $L_{R}(F)$. Basisbasis dari $L_{R}(F)$ dapat ditentukan dari subhimpunannya $\operatorname{Mon}(F)$, yaitu:

$B_{1}=\left\{u_{1}, u_{2}, u_{3}, u_{4}, e_{1}, e_{2}, e_{3}, e_{2} e_{3}, e_{1}^{*}, e_{2}^{*}, e_{3}^{*}, e_{2} e_{2}^{*}, e_{3}^{*} e_{2}^{*}\right\}$

$B_{2}=\left\{u_{1}, u_{2}, u_{3}, u_{4}, e_{1}, e_{2}, e_{3}, e_{2} e_{3}, e_{1}^{*}, e_{2}^{*}, e_{3}^{*}, e_{1} e_{1}^{*}, e_{3}^{*} e_{2}^{*}\right\}$,

$B_{3}=\left\{u_{2}, u_{3}, u_{4}, e_{1}, e_{2}, e_{3}, e_{2} e_{3}, e_{1}^{*}, e_{2}^{*}, e_{3}^{*}, e_{1} e_{1}^{*}, e_{2} e_{2}^{*}, e_{3}^{*} e_{2}^{*}\right\}$.

Secara umum, elemen dalam aljabar lintasan Leavitt $L_{R}(E)$ merupakan kombinasi linear dari elemen-elemen dalam $\operatorname{Mon}(E)$, sehingga dari (3) diperoleh:

$$
L_{R}(E)=\operatorname{span}_{R}\left\{\alpha \beta^{*}: \alpha, \beta \in \operatorname{Path}(E), r(\alpha)=r(\beta)\right\}
$$

Sebagai akibat syarat $C K 1$, perkalian dua buah monomial $\alpha \beta^{*}, \gamma \delta^{*} \in L_{R}(E)$ adalah :

$$
\left(\alpha \beta^{*}\right)\left(\gamma \delta^{*}\right)=\left\{\begin{array}{cc}
\alpha \gamma^{\prime} \delta^{*} & \text { Jika } \gamma=\beta \gamma^{\prime} \\
\alpha \delta^{*} & \text { Jika } \gamma=\beta \\
\alpha \beta^{\prime *} \delta^{*} & \text { Jika } \beta=\gamma \beta \\
0 & \text { Jika bukan salah satu kondisi di atas }
\end{array}\right.
$$


Semua sifat aljabar lintasan RE dalam Proposisi 2.3 di atas, juga tetap berlaku pada aljabar lintasan Leavitt $L_{R}(E)$. Selain $L_{R}(E)$ juga merupakan aljabar asosiatif bertingkat, syarat perlu dan cukup $L_{R}(E)$ merupakan aljabar unital dan $L_{R}(E)$ berdimensi berhingga [10].

Definisi ideal dasar dalam $L_{R}(E)$ dalam [9] tidak melibatkan basisnya $L_{R}(E)$, seolah berbeda dengan Definisi 2.4. Definisi ideal dasar dalam $L_{R}(E)$ hanya akan ditentukan oleh himpunan bagian dari $E^{0}$.

Definisi 3.4 [9] Ideal $I \subseteq L_{R}(E)$ disebut ideal dasar jika untuk setiap elemen tak nol $c \in R, v \in E^{0}$ dengan $c v \in I$ berakibat $v \in I$.

Menurut [9], sebarang ideal dasar bertingkat $J \subseteq L_{R}(E)$ terdapat subhimpunan herediter dan tersaturasi $H=J \cap E^{0}$, sehingga $J=I(H)$ dengan

$$
I(H)=\operatorname{span}_{R}\left\{\alpha \beta^{*}: \alpha, \beta \in \operatorname{Path}(E), r(\alpha)=r(\beta) \in H\right\}
$$

Ideal dasar $I(H)$ dibangun oleh subhimpunan herediter tersaturasi $H$. Jika $H$ herediter (tidak harus tersaturasi) maka dapat dibentuk ideal dasar $I(\bar{H})=I(H)$. Berdeda dengan ideal dasar dalam RE pada persamaan (2), jika subhimpunan $H$ herediter dan tidak tersaturasi maka $I_{H} \subsetneq I_{\bar{H}}$.

Contoh 3.5 Diberikan $H_{1}=\left\{u_{3}\right\} \subset F^{0}$ subhimpunan herediter dan tidak tersaturasi pada graf Gambar 2.3. Diperoleh penyaturasi dari $H_{1}$ adalah $\overline{H_{1}}=\left\{u_{2}, u_{3}\right\}$, dan

$I\left(H_{1}\right)=\operatorname{span}_{R}\left\{u_{3}, e_{3}, e_{2} e_{3}, u_{2}=e_{3} e_{3}^{*}, e_{2}=e_{2} e_{3} e_{3}^{*}, e_{2}^{*}=e_{3} e_{3}^{*} e_{2}^{*}, e_{3}^{*}, e_{2} e_{2}^{*}, e_{3}^{*} e_{2}^{*}\right\}=\quad I\left(\overline{H_{1}}\right) \cong$ $\left(\begin{array}{lll}R & R & R \\ R & R & R \\ R & R & R\end{array}\right)$ adalah ideal dasar dalam $L_{R}(F)$ yang dibangun oleh $H_{1}$. Ideal dasar dalam $R F$ yang dibangun oleh $\quad H_{1}, \quad I_{H_{1}}=\operatorname{span}_{R}\left\{u_{3}, e_{3}, e_{2} e_{3}\right\} \cong\left(\begin{array}{ccc}0 & 0 & R \\ 0 & 0 & R \\ 0 & 0 & R\end{array}\right) \quad \subsetneq\left(\begin{array}{ccc}0 & R & R \\ 0 & R & R \\ 0 & 0 & R\end{array}\right) \cong$ $\operatorname{span}_{R}\left\{u_{2}, u_{3}, e_{2}, e_{3}, e_{2} e_{3}\right\}=I_{\overline{H_{1}}}$, yang dibangun oleh $\overline{H_{1}}$.

Berdasarkan Teorema 2.7, ideal dasar $I_{\overline{H_{1}}}$ tidak prima dalam $R F$, meskipun $F^{0} \backslash \overline{H_{1}}$ merupakan ekor maksimal karena terdapat $e_{1}, r\left(e_{1}\right) \in F^{0} \backslash \overline{H_{1}}, r\left(e_{1}\right) \neq s(\vartheta)$ untuk setiap $\vartheta \in \operatorname{Path}(F)$. Namun, $I\left(\overline{H_{1}}\right)$ adalah ideal dasar prima dalam $L_{R}(F)$, tampak dari isomorfiknya $I\left(\overline{H_{1}}\right)$ dengan $M_{3}(R)$.

Perhatikan kembali konstruksi ideal dasar bertingkat dalam $R E$ dan $L_{R}(E)$ bahwa persamaan (6) merupakan perluasan dari (2), karena lintasan dalam $L_{R}(E)$ berbentuk $\alpha \beta^{*}$ dengan $\alpha, \beta \in$ $\operatorname{Path}(E), r(\alpha)=r(\beta)$. Syarat perlu dan cukup kedua dalam Teorema 2.7: untuk setiap lintasan $\mu$ dengan $r(\mu) \in M=E^{0} \backslash H$, terdapat lintasan $\vartheta \in \operatorname{Path}(E)$ sedemikian sehingga $r(\mu)=s(\vartheta)$ dan $s(\mu)=r(\vartheta)$, selalu terpenuhi oleh ideal dasar $I(H)$ pada persamaan (6) dengan $H$ subhimpunan herediter tersaturasi. Telah menemukan syarat perlu dan cukup ideal dasar bertingkat $I(H)$ dalam $L_{R}(E)$ merupakan ideal dasar prima [11].

Teorema 3.6 [11] Diberikan Graf $E$ dan $H \subset E^{0}$ adalah herediter tersaturasi. Ideal dasar (bertingkat) $I(H)$ dalam $L_{R}(E)$ adalah ideal dasar prima jika dan hanya jika $M=E^{0} \backslash H$ memenuhi kondisi (MT3).

Bukti lengkap Teorema 3.6 dapat disimak dalam [11, Teorema 3.5]. Berdasarkan persamaan (6) ideal dasar $I(\varnothing)=\{0\}$ dalam $L_{R}(E)$, dan menurut Lemma 1.8, $E^{0}$ senantiasa memenuhi (MT1) dan $(M T 2)$. Artinya, ideal $\{0\}$ dalam $L_{R}(E)$ merupakan ideal dasar prima jika dan hanya jika $E^{0}$ memenuhi (MT3).

Akibat 3.7 [11] Aljabar lintasan Leavitt $L_{R}(E)$ bersifat prima mendasar jika dan hanya jika $E^{0}$ memenuhi kondisi (MT3). 
Contoh 3.8 Perhatikan kembali Gambar 2.2 di atas, bahwa $D^{0}, G^{0}$ keduanya memenuhi kondisi (MT3), sehingga aljabar lintasan Leavitt $L_{R}(D)$ dan $L_{R}(G)$ adalah prima mendasar. Berdasarkan Contoh 2.9, $F^{0}$ tidak memenuhi (MT3), maka $L_{R}(F)$ tidak prima mendasar.

\section{Pengembangan Aljabar Lintasan dan Aljabar Lintasan Leavitt}

Perhatikan kembali Contoh 3.5, $I_{\overline{H_{1}}}$ bukan ideal dasar prima dalam $R F$. Selain itu, terdapat ideal dasar $J=\operatorname{Span}\left\{e_{1}\right\} \cong\left(\begin{array}{ll}0 & R \\ 0 & 0\end{array}\right)$ di $R F$ dengan $J^{2}=\{0\} \subset I_{\overline{H_{1}}}$ tetapi $J \nsubseteq I_{\overline{H_{1}}}$ maka ideal dasar $I_{\overline{H_{1}}}$ tidak semiprima. Perhatikan graf $T$ dengan $T^{0}=\{u, v, w\}, T^{1}=\{e, f\}$ yang dilukiskan pada gambar di bawah ini. Diberikan $X=\{w\} \subset T^{0}$ yang herediter tersaturasi dan $T^{0} \backslash X$ tidak memenuhi (MT3). Menurut Teorema 2.7, ideal dasar $I_{X}=\operatorname{span}_{R}\left\{w, f, e f, e^{2} f, \ldots, e^{n} f, \ldots\right\}$ tidak prima. Namun

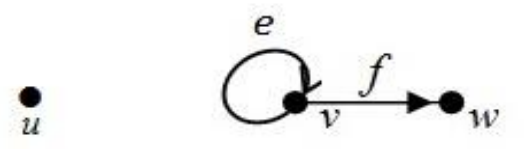

$I_{X}$ merupakan ideal dasar semiprima. jelas dari Gambar di samping bahwa setiap lintasan $\mu$ dengan $r(\mu) \in T^{0} \backslash X$, terdapat $\vartheta \in \operatorname{Path}(T)$ sehingga $r(\mu)=s(\vartheta)$ dan $s(\mu)=$ $r(\vartheta)$. Syarat ini tidak dipenuhi oleh $I_{\overline{H_{1}}}$.

Ideal dasar prima merupakan ideal dasar semiprima, tetapi tidak sebaliknya. Kasus $I_{X}$ di atas mengilustrasikan syarat kedua dalam Teorema 2.7 merupakan syarat perlu dan cukup $I_{H}$ semiprima.

Teorema 4.1 Diberikan aljabar lintasan $R E$ dan subhimpunan herediter tersaturasi $H \subset E^{0}$. Ideal $I_{H} \subseteq$ $R E$ adalah ideal dasar semiprima jika dan hanya jika untuk setiap lintasan $\mu$ dengan $r(\mu) \in M=$ $E^{0} \backslash H$, terdapat $\vartheta \in \operatorname{Path}(E)$ sedemikian sehingga $r(\mu)=s(\vartheta)$ dan $s(\mu)=r(\vartheta)$.

Bukti : $(\Rightarrow)$ Andaikan terdapat lintasan $\mu$ dengan $r(\mu) \in M$, sehingga $r(\mu) \neq s(\vartheta)$ atau $s(\mu) \neq r(\vartheta)$ untuk setiap lintasan $\vartheta \in \operatorname{Path}(E)$. Akibatnya, $\mu R E \mu=\{0\} \subset I_{H}$. Karena ideal dasar $I_{H}$ semiprima maka $\mu \in I_{H}$ sehingga $r(\mu) \in H$, kontradiksi dengan $r(\mu) \in E^{0} \backslash H$. $(\Leftarrow)$ Andaikan ideal dasar $I_{H}$ tidak semiprima. Artinya, terdapat lintasan $\alpha$ sehingga $\alpha R E \alpha \subseteq I_{H}$ tetapi $\alpha \notin I_{H}$ atau $r(\alpha) \in M$. Jika $\alpha R E \alpha \neq\{0\}$ maka terdapat lintasan $\beta$ sehingga $0 \neq \alpha \beta \alpha \in I_{H}$. Artinya, $r(\alpha \beta \alpha)=r(\alpha) \in H$, sehingga $\alpha \in I_{H}$ yang kontradiksi dengan $\alpha \notin I_{H}$. Jika $\alpha R E \alpha=\{0\}$ maka untuk setiap lintasan $\gamma$ berlaku $\alpha \gamma \alpha=$ 0 , sehingga $r(\alpha) \neq s(\gamma)$ atau $s(\alpha) \neq r(\gamma)$. Hal ini kontradiksi dengan hipotesis, sehingga haruslah $I_{H}$ semiprima.

Kesemiprimaan mendasar aljabar lintasan bergantung kesemiprimaan dari ideal dasar $\{0\}$. Secara analog Akibat 2.8, Teorema 4.1 memiliki akibat berikut.

Akibat 4.2 Aljabar lintasan RE merupakan aljabar semiprima mendasar jika dan hanya jika untuk setiap lintasan $\mu$, terdapat lintasan $\vartheta$ sedemikian sehingga $r(\mu)=s(\vartheta)$ dan $s(\mu)=r(\vartheta)$.

Setiap lintasan real $\mu$ dalam aljabar lintasan $R \hat{E}$ terdapat $\mu^{*}$, yakni lintasan hantu sedemikian sehingga $r(\mu)=s\left(\mu^{*}\right)$ dan $s(\mu)=r\left(\mu^{*}\right)$. Hal ini berarti bahwa $R \hat{E}$ selalu semiprima mendasar. Aljabar lintasan Leavitt $L_{R}(E)$ merupakan aljabar lintasan $R \hat{E}$ yang memenuhi Definisi 3.1, sehingga Akibat 4.2 berakibat berikut.

Akibat 4.3 Aljabar lintasan Leavitt $L_{R}(E)$ pasti semiprima mendasar.

Akan dicari syarat perlu dan cukup $L_{R}(E)$ bersifat semiprima. Proses pembuktiannya memerlukan Teorema Reduksi (The Reduction Theorem) dalam [3, Theorem 2.2.11] yang menyatakan bahwa setiap elemen tak nol $x \in L_{R}(E)$ terdapat lintasan $\alpha, \beta \in$ Path $(E)$ sedemikian hingga

(i) $0 \neq \alpha^{*} x \beta \in R v$ untuk suatu $v \in E^{0}$ atau

(ii) $0 \neq \alpha^{*} x \beta=p(c)$ dengan $c$ suatu sikel tanpa jalan keluar dan $p(c)$ polinomial tak nol dalam $R\left[x, x^{-1}\right]$. 
Perhatikan kembali $L_{R}(F)$ pada Contoh 3.2, jika ring $R$ diganti $\mathbb{Z}_{4}$ yang tidak semiprima maka $L_{\mathbb{Z}_{4}}(F)$ semiprima mendasar tetapi tidak semiprima. Karena, terdapat ideal tak nol $J \cong$ $M_{3}(\{\overline{0}, \overline{2}\}) \times M_{2}(\{\overline{0}, \overline{2}\})$ dalam $L_{\mathbb{Z}_{4}}(F)$, dengan $J^{2}=\{0\}$. Kesemiprimaan $L_{R}(E)$ tidak bergantung pada struktur grafnya.

Teorema 4.4 Aljabar lintasan Leavitt $L_{R}(E)$ adalah semiprima jika dan hanya jika ring komutatif unital $R$ juga semiprima.

Bukti : $\Leftrightarrow$ Andaikan $R$ tidak semiprima, maka terdapat elemen taknol $k \in R$, sehingga $k^{2}=0$. Karena $k \neq 0$, maka $k v \neq 0$ untuk setiap titik $v \in E^{0}$, dan terdapat $\mu \in L_{R}(E)$ sedemikian sehingga $k v \mu k v \neq 0$ dikarenakan $L_{R}(E)$ semiprima. Dapat ditulis $\mu=\sum_{i=1}^{m} k_{i} \alpha_{i} \beta_{i}^{*}$ untuk suatu $k_{i} \in R, \alpha_{i}, \beta_{i} \in$ $\operatorname{Path}(E), m \in \mathbb{N}$, sehingga

$k v \mu k v=k v\left(\sum_{i=1}^{m} k_{i} \alpha_{i} \beta_{i}^{*}\right) k v=v\left(\sum_{i=1}^{m} k k_{i} k \alpha_{i} \beta_{i}^{*}\right) v=v\left(\sum_{i=1}^{m} k^{2} k_{i} \alpha_{i} \beta_{i}^{*}\right) v=0, \quad$ dan $\quad$ terjadilah kontradiksi. Diperoleh $R$ semiprima. $(\Leftarrow)$ Sebaliknya, andaikan $L_{R}(E)$ tidak semiprima. Artinya, terdapat ideal tak nol $\mathfrak{I} \subset L_{R}(E)$ sehingga $\mathfrak{I}^{2}=\{0\}$. Ambil $0 \neq x \in \mathfrak{I}$ maka dengan Teorema Reduksi dapat ditemukan $\alpha, \beta \in \operatorname{Path}(E)$ sehingga memenuhi (i) atau (ii). Kasus (i), $0 \neq \alpha^{*} x \beta=k v \in \mathfrak{J}$. Kesemiprimaan $R$ berakibat $k^{2} \neq 0$ dan $0 \neq k^{2} v=(k v)^{2} \in \mathfrak{J}^{2}=\{0\}$ adalah suatu kontradiksi. Kasus ke (ii), $0 \neq \alpha^{*} x \beta=p(c) \in \mathfrak{J}$. Karena $R$ semiprima dan juga $R\left[x, x^{-1}\right]$, maka $p(c)^{2} \neq 0$. Diperoleh, 0 $\neq p(c)^{2} \in \mathfrak{I}^{2}=\{0\}$ juga suatu kontradiksi. Jadi, $L_{R}(E)$ semiprima.

Telah dibahas suatu ideal admisibel (admissible ideal) dalam aljabar lintasan $K E$, sebagai ideal sisi yang mempunyai syarat tertentu [7]. Bagaimana dapat dikonstruksi ideal dasar admisibel dalam aljabar lintasan $R E$ berdasarkan konstruksi ideal dasarnya. Jika konstruksi ini berhasil, dapat dilanjutkan pembentukan aljabar faktor dari $R E$ berkaitan dengan ideal dasar admisibelnya.

Selain sifat sederhana, prima dan semiprima mendasar, dapat dikembangkan klasifikasi lain $R$ aljabar bebas berdasarkan ideal dasarnya, seperti $R$-aljabar reguler, reguler kuat, reguler lemah, primitif beserta sifat-sifatnya. Implementasi hasil penelitian yang mungkin adalah mencari syarat perlu dan cukup aljabar $R E$ dan $L_{R}(E)$ mempunyai klasifikasi khusus tersebut. Masih banyak masalah terbuka dapat dikaji dari aljabar lintasan dan aljabar lintasan Leavitt, yang tidak hanya pengembangan aljabar, tetapi analisis dan terapannya.

\section{Penutup}

Aljabar lintasan $R E$ dan aljabar lintasan Leavitt $L_{R}(E)$ atas ring komutatif unital $R$ dikonstruksi dari semigrupring yang merupakan aljabar asosiatif sekaligus bebas. Ideal dasar dalam $R E$ dapat dibentuk dari subhimpunan herediter tersaturasi dalam $E^{0}$, demikian juga ideal dasar dalam $L_{R}(E)$. Sifat prima mendasar, semiprima mendasar dalam $R E$ maupun $L_{R}(E)$ didefinisikan berdasarkan ideal dasarnya.

Keprimaan mendasar aljabar lintasan $R E$ dan aljabar lintasan Leavitt $L_{R}(E)$ bergantung pada struktur grafnya, demikian pula kesemiprimaan mendasar dari $R E$. Sebarang $L_{R}(E)$ bersifat semiprima mendasar, namun belum tentu semiprima. Aljabar lintasan Leavitt aljabar lintasan Leavitt $L_{R}(E)$ semiprima jika dan hanya jika ring komutatif unital $R$ juga semiprima. Karena lapangan $K$ senantiasa semiprima, maka sebarang aljabar lintasan Leavitt $L_{K}(E)$ adalah semiprima.

\section{Referensi}

[1] Abrams, G. and Aranda Pino, G., 2008, The Leavitt Path Algebra of Arbitrary Graph, Houston J. Math., 34, pp. 423442 .

[2] Abrams, G., Aranda Pino, G., and Molina, M.S., 2008, Locally Finite Leavitt Path Algebra, Israel J. Math., 165, pp. 329-348.

[3] Abrams, G., Ara, P. and Molina M.S., 2014, Leavitt Path Algebras, A Primer and Handbook, Springer, To appear. https://www.dropbox.com/s/ gqqx735jddrip8f/AbramsAraSiles_BookC1C2.pdf/dl=0 
[4] Aranda Pino, G., Perera, F., Molina, M. S., 2007, Graph algebras: bridging the gap between analysis and algebra, University of Malaga Press, Spain.

[5] Aranda Pino, G., Pardo, E., Molina, M.S., 2009, Prime Spectrum and Primitive Leavitt Path Algebras, Indiana Univ. Math. Journal 58, 869890.

[6] Aranda Pino, G. , Barquero, D. M., Gonzalev, C. M., Molina, M. S., 2010, Socle Theory for Leavitt Path Algebra of Arbitrary Graph, Rev. Mat Iber. 26, pp. 611638.

[7] Assem, I., Simson, D., Skowronski, A., 2005, Elements of the Representation Theory of Associative Algebras, Cambridge University Press, New York.

[8] Passman, D., 1997, The Algebraic Structure of Group Rings, John Wiley and Sons, New York.

[9] Tomforde, M., 2011, Leavitt Path Algebras With Coefficient In A Commutative Ring, J. Pure Appl. Algebra 215, pp. 471-484.

[10] Wardati, K., Wijayanti, I.E., Wahyuni, S., 2011, The Cuntz-Krieger Uniqueness Theorem of Leavitt Path Algebras, Proceedings of The 6th SEAMS-UGM Conference 2011 Algebra, pp. 183192.

[11] Wardati, K., Wijayanti, I.E., Wahyuni, S., 2014, Keprimaan Mendasar Aljabar Lintasan Leavitt Atas Ring Komutatif, Artikel dipresentasikan dalam Seminar Nasional Aljabar dan Pengajarannya, di Jurusan Matematika Universitas Hasanudin Makassar, 34 Mei, 2014.

[12] Wardati, K., Wijayanti, I.E., Wahyuni, S., 2014, On Primeness of Path Algebras over a Commutative Unital Ring, JP Journal of Algebra, Number Theory and Applications, 34 (2), pp. 121138.

[13] Wardati, K., Wijayanti, I.E., Wahyuni, S., 2015, On Free Ideal in Free Algebra over a Ring, J. Indones. Math. Soc., 21 (1), pp. 5969. 